\title{
HAKIKAT PLURALISME DI INDONESIA PERSPEKTIF NURCHOLISH MADJID
}

\section{ESSENCE PLURALISM IN INDONESIA BY NURCHOLISH MADJID PERSPECTIVE'S}

\author{
Fahrul Rozi \\ IAIN Syekh Nurjati
}

fahrulrozi1911@gmail.com

\begin{abstract}
ABSTRAK: Dewasa ini, kita seringkali menyaksikan realitas dimana agama hadir bukan lagi sebagai alat pemersatu umat, namun agama justru menimbulkan skisma. Dampaknya terdapat keistimewaan terhadap kaum mayoritas dan diskriminasi terhadap kaum minoritas. Hal ini disebabkan karena mindset common sense (masyarakat umum) bersifat eksklusif dan bukan inklusif. Okeh karena itu, Nurcholish Madjid lahir sebagai pemikir dan sekaligus cendekiawan muslim yang membuka pikiran umat agar dapat menerima perbedaan. Apa yang ia sebut sebagai "teologi inklusif" lahir sebagai solusi atas masalah pluralisme di Indonesia. la menyatakan jika semua agama adalah Islam secara hakikat, karena semua agama berintikan ajaran "pasrah kepada Tuhan". Nurcholis Madjid mengajak kita untuk membuka mata kita dan melihat perbedaan sebagai suatu anugerah Tuhan. Sehingga dengan perbedaan itu, justru kita harus bersatu dalam perspektif Bhinneka Tunggal lka.

Kata Kunci: Nurcholish Madjid, Skisma, Pluralisme, Agama.
\end{abstract}

ABSTRACT: At last, we often witness the reality that religion exists no longer as a unifying people, but religion actually raises schism. The impact of it are the society majority have a privilege and discrimination for minority society. This phenomenon resulted by mindset of common sense who exclusive and not inclusive. Therefore, Nurchlolish Madjid born as thinker and also as a Moslem scientist who open the think of society suppose can accept differences. What who mentioned as "inclusive theology" born as solve upon the pluralism problem. He said that all of religion are same according to the reality, because all of religion are had basic though to "surrender to God". Nurchlolish Madjid let us to open our eyes snd see the differences as a gift from God. So with that difference, exactly we must integrate in the Bhinneka Tunggal lka perspective.

Keyword: Nurcholish Madjid, Schism, Pluralism, Religion.

\section{A. PENDAHULUAN}

Indonesia memiliki beberapa agama dan kepercayaan. Salah satu agama yang dianut oleh mayoritas masyarakat Indonesia adalah agama Islam. Agama Islam memiliki penganut paling banyak di Indonesia dan menjadikan Indonesia termasuk kepada negara dengan penganut Islam terbanyak di dunia. Agama Islam diperkirakan masuk ke Indonesia pada abad ke-7 M. Namun, ada juga yang mengatakan bahwa Islam masuk ke Indonesia pada abad ke-13 M. Para ahli masih berbeda pendapat tentang hal ini sehingga masih belum dapat dipastikan kapan tepatnya Islam masuk ke Indonesia ${ }^{1}$.

\footnotetext{
${ }^{1}$ Khairiah Jarir, Meneliti Situs-Situs Awal Peradaban di Pulau Bengkalis, Akademia, Vol 14, 2 Desember 2018. Hlm. 85-97.
} 
Berdasarkan dari catatan-catatan sejarah, setidaknya ada tiga teori besar tentang kedatangan Islam ke Indonesia, yaitu teori mekah, teori gujarat, dan teori persia. Teori Mekah dikemukakan oleh Prof. Dr. H. Abdul Malik Karim Amrullah atau Buya Hamka. Ia mengemukakan beberapa fakta, yakni; (1) Islam masuk ke Indonesia pada abad ke-7 Masehi atau tahun pertama Hijriah. Hal ini dibuktikan dengan adanya perkampungan pedagang Arab Islam di Pantai Barat Sumatera pada 674 M; (2) Jalur perdagangan antara Arab dan China sudah ada sebelum Masehi, tepatnya berlangsung sejak 500 SM. Jalur yang menghubungkan kedua negara ini dikenal dengan sebutan jalur sutera.

Teori kedua yang menjelaskan masuknya Islam adalah teori Gujarat. Teori ini dikemukakan oleh Snouck Hurgronje sebagai peletak dasar teori ini. Pada teori kedua ini penulis tulis secara kronologis kendatipun sumber buku tidak menuliskan secara demikian. Teori ini menjelaskan bahwasannya Islam masuk ke Nusantara dilatarbelakangi dan sekaligus dikuatkan oleh teori yang mejelaskan bahwa hubungan perdagangan antara Nusantara dengan Gujarat atau India yang telah lama terjalin. Disamping itu, kurangnya fakta yang menjelaskan peranan bangsa Arab dalam penyebaran agama Islam ke Nusantara turut memperkuat teori ini. Bukti selanjutnya adalah, inskripsi tertua tentang Islam terdapat di Sumatera dengan Gujarat.

Bersamaan dengan pendapat dan sekaligus teori yang dikemukakan oleh Snouck Hurgronje, seorang W.F Stutterheim pun turut mengafirmasi teori Gujarat yang dikemukakan oleh Snouck Hurgronje ini. Dalam bukunya, De Islam enzijn Koimst In de Archipel, W.F Stutterheim menyatakan jika adanya kesamaan antara relief nisan Sultan Malik Al-Saleh dengan nisan yang terdapat di Gujarat. ${ }^{2}$ Sultan Malik Al-Saleh sendiri wafat pada 1297. Namun masih dalam pembahasan yang sama bahwasannya tidak sepenuhnya Islam masuk ke Nusantara karena terpengaruh oleh Gujarat. ${ }^{3}$ Sehingga apa yang kemudian dikemukakan oleh J.C Van Leur dalam bukunya Indonesia : Trade and Society mentayakam jika pada tahun 674 di pantai barat Sumatera terdapat perkampungan atau koloni Arab Islam. Hal ini tentu dengan pertimbangan yang menyatakan jika Bangsa Arab telah menjadikan perkampungan perdagangan di Kanton pada abad ke-4. Sehingga

\footnotetext{
${ }^{2}$ Dra. Hj. Enung K Rukiati dan Dra. Fenti Hikmawati. Sejarah Pendidikan Islam di Indonesia. 2006. Bandung : Pustaka Setia, hlm. 23

${ }^{3}$ Dra. Hj. Enung K Rukiati dan Dra. Fenti Hikmawati. Sejarah Pendidikan Islam di Indonesi. 2006.

Bandung : Pustaka Setia, hlm. 24
} 
teori Gujarat ini memiliki kelemahan jika dibandingkan dengan teori Mekah yang dikemukakan oleh Buya Hamka.

Teori ketiga yang juga merupakan teori masuknya Islam dikemukakan oleh Hoesein Djajadiningrat. Teori ketiga ini dikenal dengan sebutan teori Persia. Teori ini memiliki persamaan dengan teori Gujarat yang menyatakan bahwa Islam masuk ke Nusantara pada abad ke-13. ${ }^{4}$ Namun terdapat hal-hal yang membuatnya berbeda dengan teori Gujarat. Perbedaan itu adalah terdapat perbedaan sistem tasawuf antara PersiaIndonesia dengan Gujarat. Gujarat lebih bersifat Hindu Sentris.

Selanjutnya kita beralih kepada kesamaan antara Nusantara dengan Persia. Pertama, peringatan 10 Muharram atau Assura sebagai hari peringatan Syiah atas kematian syahidnya Husain. Kedua, adanya kesamaan ajaran sufi antara Syekh Siti Jenar dengan Al-Hallaj. Terakhir adalah sistem mengeja huruf Arab, dimana untuk tanda-tanda bunyi harkat pengajian Al-Quran tingkat awal terdapat hukumnya sendiri.

\begin{tabular}{|c|c|}
\hline Bahasa Arab & Bahasa Persia \\
\hline Jabar-Zabar & Fathah \\
\hline Jer-Zeer & Kasrah \\
\hline P'es-Py'es & Dhammah \\
\hline
\end{tabular}

Sehingga dari ketiga teori yang telah dikemukakan di atas, bahwasannya ketiga teori tersebut memiliki kekurangan dan kelebihan masing-masing. Namun kita harus tahu juga, bahwa sejarah merupakan ilmu yang tingkat subjektivitasnya cukup tinggi. Maka yang terpenting adalah kita tahu persamaan dan perbedaannya. Untuk persamaan antara teori Gujarat dan Persia terletak pada tahun masuknya Islam ke Nusantara, yaitu pada abad ke-13. Sedangkan perbedaannya bahwa, teori Mekah menegaskan tahun masuknya Islam bukan pada abad ke-13, melainkan teori Mekah mengklaim bahwa Islam masuk ke Indonesia pada abad ke-7.

Teori Mekah juga menyatakan jika pembawa agama Islam adalah saudagar Arab dan kemudian diikuti oleh orang Persia dan Gujarat. Teori Mekah juga mengatakan Persia dan Gujarat hanyalah tempat singgah, sehingga ajaran Islam yang murni diambilnya dari Mekah atau Mesir. Maka oleh karena teori Mekah yang lebih banyak mengembangkan bukti, teori tersebut juga mendapatkan legitimasi yang dimana Teori Hamka mendapat

\section{${ }^{4}$ Ibid}


perhatian dan pembenaran dalam seminar-seminar seperti: Sejarah Islam ke Indonesia (1963), Sejarah Islam di Minangkabau (1969), Sejarah Riau (1975), Masuknya Islam di Kalimantan (1976), dan Seminar Pendahuluan Sejarah Islam di Indonesia (1980). ${ }^{5}$

\section{B. HASIL DAN PEMBAHASAN}

\section{Biografi Nurcholis Madjid}

Nurcholis Madjid lahir di Jombang, Jawa Timur pada 17 Maret 1939. Nurcholis Madjid merupakan sosok santri yang dimana ayahnya merupakan lulusan Pesantren Tebu Ireng dan secara personal ayahnya mempunyai hubungan dekat dengan KH. Hasyim Asy'ari yang merupakan salah seorang pendiri NU. Ibunya juga berasal dari kalangan NU, Nurcholis Madjid merupakan adik dari seorang Rais Akbar NU, dari seorang ayah seorang aktivis Sarekat Dagang Islam (SDI) di Kediri, Jawa Timur.

Jombang yang merupakan jantung Islam Jawa pada masa Nurcholis Madjid kecil. Ia mengalami satu fase yang dinamakan "ketegangan budaya." Ketegangan budaya disebabkan karena Nurcholis Madjid membenci komunitas yang disebutnya sebagai penganut "abanganisme" pada masanya itu. ${ }^{6}$ Ia membenci komunitas itu disebabkan karena kerap kali menggilas anak-anak sendiri.

Menurut pengakuannya, Nurcholis Madjid sendiri untuk pertama kalinya belajar agama dari kedua orang tuanya. Ia menjadi murid dari kedua orang tuanya, karena kedua orang tuanya tersebut merupakan pendiri madrasah dimana Nurcholis Madjid belajar. Nurcholis Madjid kecil mengikuti Sekolah Rakyat (SR) dikampungnya dan tamat pada tahun 1952. Setelah lulus, Nurcholis Madjid melanjutkan studinya ke Pesantren Darul Ulum, Rejosa, Jombang. Namun hanya bertahan selama dua tahun saat bersekolah di Darul Ulum. Disana ia sempat menyelesaikan tingkat Ibtidaiyah, dan melanjutkan ke tingkat Tsanawiyah. ${ }^{7}$

\footnotetext{
${ }^{5}$ Dra. Hj. Enung K Rukiati dan Dra. Fenti Hikmawati. Sejarah Pendidikan Islam di Indonesia. 2006. Bandung : Pustaka Setia, hlm. 27

6 http://garuda.ristekdikti.go.id/documents/detail/1250181_diunduh pada 25/02/2020 pukul 05.05

\section{${ }^{7}$ Ibid}


Terdapat dua faktor yang menyebabkan Nurcholis Madjid keluar dari Madrasah Darul Ulum, tempat ia belajar. Pertama, disebabkan alasan kesehatan yang kurang menunjang, dan yang kedua karena alasan ideologis serta politik. Namun alasan politik adalah hal yang paling dominan. Seperti yang diketahui, pada 1952, NU keluar dari Masyumi dan sejak saat itu NU dan peran Jam'iyah keagamaan menjadi partai politik. Namun ketika NU memisahkan diri dari Masyumi, ayahnya tetap memilih Masyumi. Ayahnya aktif dalam organisasi tradisional NU, dan partai politik dibawah pengaruh modernisasi Islam, Masyumi.

Menurut pengakuannya, sang ayah kecewa karena melihat NU yang memisahkan diri dari Masyumi dan lebih memilih untuk mendirikan partai politik sendiri. Karena status ayahnya itulah, Nurcholis Madjid dijuluki teman-temannya di NU sebagai “anak Masyumi kesasar.” Menurut pengakuan Nurcholis Madjid sendiri, ayahnya dimusuhi oleh kyai Jombang, lalu Nurcholis Madjid meminta ayahnya untuk pindah ke NU. Namun ayahnya menolak dengan alasan, yang dapat berpolitik dinilainya hanyalah Masyumi dan bukan NU. Sikap ayah yang teguh pada politik Masyumi dan disisi lain menjaga anggota NU membuat Nurcholis Madjid tak bertahan lama di Darul Ulum. Ia meminta ayahnya agar memindahkannya ke sekolah lain. ${ }^{8}$

Pada tahun 1955, Nurcholis Madjid dipindahkan Oleh ayahnya menuju Pesantren Darussalam Gontor. Ayahnya berasumsi bahwa Gontor merupakan pesantren Masyumi. Nampaknya Nurcholis Madjid merasa lebih cocok belajar di Gontor ketimbang di Darul Ulum. Menurut pengakuannya, Gontor adalah tempat yang memberikan inspirasi terhadapnya terutama kepada tiga hal pokok yang kelak akan menjadi corak pemikirannya. Tiga hal tersebut adalah, modernisasi, non-sektarianisme, dan pluralisme.

Pluralisme di Pesantren ini cukup terjaga, hal ini dibuktikan dengan adanya izin bagi santri untuk bergaul dengan orang-orang NU ataupun Muhammadiyah. Dengan suasana yang demikian, maka Nurcholis Madjid merasa cocok belajar di Gontor.

Nurcholis Madjid pun termasuk santri yang cerdas, dimana ia dapat meraih prestasi yang cukup mengagumkan. Ia meraih juara kelas yang

\footnotetext{
${ }^{8}$ Ibid
} 
menyebabkannya mampu melakukan "akselerasi" dari kelas I langsung loncat ke kelas III SMP. Nurcholis Madjid mengakui bahwa, di Gontor ia selalu meraih prestasi yang cukup baik. Tak sampai disitu, karena kecerdasannya, pimpinan pondok Pesantren Gontor, KH. Zarkasyi bermaksud untuk mengirim Nurcholis Madjid ke Universitas Al-Azhar, Kairo. Namun karena kendala yang terjadi pada masa itu (krisis terusan Suez), sehingga ia gagal diberangkatkan. Oleh karena hal tersebut, Nurcholis Madjid mengajar selama satu tahun di Pesantren Gontor. ${ }^{9}$

Setelah ia mengajar selama satu tahun di Gontor, ia lalu mendaftarkan diri sebagai mahasiswa di IAIN Jakarta dan diterima sebagai mahasiswa fakultas adab. Lagi-lagi Nurcholis Madjid membuat prestasi baru, dimana ia melanjutkan studinya di Chicago, Amerika Serikat hingga program doktoral.

Pada tahun 1984, ia memeroleh gelar philosophy Doctoral (Ph.D) di Universitas Chicago dengan predikat cumlaude. Adapun disertasinya, ia mengangkat pemikiran Ibnu Taymiyah dengan judul "Ibn Taymiyah dalam Ilmu Kalam dan Filsafat: masalah akal dan wahyu dalam Islam” (Ibn Taymiyah in Kalam and Falsafah: a problem of reason and revelation in Islam). Dari disertasinya, menunjukkan bahwa dirinya sangat mengagumi tokoh tersebut. ${ }^{10}$

\section{Pengertian Pluralisme}

Pluralisme merupakan deskripsi dari adanya kemajemukan suku, bangsa, agama, maupun segala sesuatu yang terdapat dalam masyarakat tertentu. Banyak orang memahami pluralisme sebagai suatu sikap mengakui, saling menghargai, saling menghormati, bahkan berusaha untuk mengembangkan kemajemukan tersebut. Hal tersebut jelas sangat keliru, bahkan hal ini masih saja terjadi di kalangan akademisi yang notabene bukan masyarakat awam.

Jika sikap yang sudah penulis sebutkan di atas, antara lain sikap saling mengakui, sikap saling menghargai, dan sikap saling menghormati. Ketiga hal tersebut adalah pengejawantahan dari istilah toleransi. Sehingga sangat penting

\footnotetext{
${ }^{9}$ Ibid

${ }^{10}$ Ibid
} 
bagi kita untuk sesuatu hal yang nampaknya remeh temeh namun sangat krusial sekali. ${ }^{11}$

Selain itu pluralisme juga dapat dipahami sebagai sifat daripada keanekaragaman didalam suatu masyarakat terhadap suatu hal tertentu (objek), namun dengan perbedaan tersebut diperlukan sikap yang bernama toleransi, seperti yang sudah penulis katakan sebelumnya. ${ }^{12}$

Berbicara soal pluralisme, tidak elok nampaknya jika kita tidak membahas soal cara pandang seseorang atau dalam hal ini perspektif. Dengan adanya perbedaan tentu kita tidak dapat menegasikan adanya perbedaan persepektif satu orang dengan orang yang lain terhadap objek tertentu. Baik, disini terdapat dua perspektif dalam memandang pluralisme. Pertama, adalah perspektif praktis, dan yang kedua adalah perspektif ideologis.

Perspektif praktis dapat dipahami sebagai suatu sikap yang saling menghormati, saling menghargai satu sama lain (antar masyarakat yang berbeda dalam hal tertentu). Perspektif ideologis merupakan suatu hal yang menyangkut keyakinan masing-masing orang. Misalnya saja memandang semua agama adalah benar, hal ini tentu sifatnya subjektif, yang berarti setiap orang dapat berbedabeda. Hal yang sebenernya tidak terlalu prinsipil namun tiap orang dapat melakukan interpretasi yang berbeda. Kendatipun sama dalam hal intepretasi, namun sama dalam hal esensi. ${ }^{13}$

Dengan demikian, penting bagi kita untuk membedakan dua terminologi tersebut (pluralisme dan toleransi) yang kerap kali disatumaknakan oleh orangorang yang tidak mengerti. Penulis pernah melihat penulis jurnal yang memang masih saja menyamartikan kedua terminologi tersebut. Padahal statusnya bukan lagi common sense (masyarakat awam), melainkan seorang akademisi, seperti yang sudah penulis singgung sebelumnya.

11 http://garuda.ristekdikti.go.id/documents/detail/1250181_diunduh pada 25/02/2020 pukul 05.05 
Secara bahasa, pluralisme diambil dari bahasa Inggris plural $^{14}$ yang berarti jamak atau banyak. Sedangkan toleransi secara Kamus Besar Bahasa Indonesia (KBBI), merupakan sikap membiarkan orang lain dengan berpegang pada nilainilai atau keyakinan yang dianggapnya benar. ${ }^{15}$ Singkatnya , pluralisme hanya bersifat deskriptif, karena menjelaskan keadaan masyarakat tertentu yang didalamnya terdapat perbedaan-perbedaan. Sedangkan toleransi merupakan sikap yang harus kita ambil dengan adanya perbedaan-perbedaan tersebut. ${ }^{16}$

\section{Padangan Nurcholis Madjid terhadap Pluralisme Agama}

Secara Kebhinekaan atau ke-Indonesia-an, maka makna pluralisme tentu saja tercermin dalam sila pertama Pancasila yaitu "Ketuhanan Yang Maha Esa." Dimana Pancasila bukan hanya berafiliasi pada agama tertentu saja, Islam misalnya, namun justru majemuk (plural). Maka prinsip Bhinneka Tunggal Ikalah yang harus benar-benar melekat dalam setiap individu Indonesia. ${ }^{17}$

MUI atau Majelis Ulama Indonesia membuat definisi baru mengenai pluralisme. Pihaknya mengartikan jika pluralisme merupakan semua agama mengajarkan kebaikan dan bukan keburukan. Sehingga adanya klaim sepihak bahwa agama ini benar dan yang lain salah jelas bukan cermin dari sila pertama Pancasila. Sehingga, toleransi lah yang nantinya akan menjadi puncak sikap di negara majemuk seperti Indonesia.

Islam sendiri telah mengakui adanya paham pluralisme, dimana adanya keteguhan dan keyakinan yang kuat terhadap ajaran agamanya sendiri. Sehingga dengan demikian, kita tidak lagi mencampuri urusan agama orang lain dengan urusan agama kita, selaku Muslim misalnya. Islam sebagai agama yang rahmatan Lil alamin berarti berlaku bagi seluruh alam dan seluruh makhluk, tidak terkecuali.

Nurcholis Madjid sendiri mengartikan pluralisme sebagai suatu hal yang terdiri atas nilai-nilai yang membentuk sistem yang berikan pandangan positif dan optimis terhadap suatu kemajemukan dengan cara menerimanya sebagai

\footnotetext{
14 Kamus Bahasa Inggris

${ }^{15}$ Kamus Besar Bahasa Indonesia

${ }^{16}$ Ibid

${ }^{17}$ Ibid
} 
kenyataan dan berbuat baik berdasarkan kenyataan itu. Nurcholis Madjid memiliki pandangan inklusivisme, dimana Islam hakikatnya merupakan agama yang terbuka. Sehingga karena hal ini, Islam tentu tidak menutup mata dari adanya kemajemukan. Islam justru mengerti, menghargai perbedaan-perbedaan itu dan menyikapinya dengan sikap bijaksana dan arif. Sehingga dengan keterbukaan inilah yang nantinya akan memunculkan dialektika atau dialog antar orang-orang yang berbeda suku, agama, ras, dan budaya. Dengan demikian muncullah apa yang disebut sebagai "kehangatan berwarganegara." 18

Nurcholis Madjid juga tidak mengafirmasi jika semua agama memiliki kebenaran yang absolut, justru ajaran agama lain terdapat hal-hal serupa juga dalam agama Islam misalnya. Namun dalam ini kita tidak menafikkan Islam sebagai agama kita sendiri misalnya. Oleh karena itu, sikap saling keterbukaan, saling menghargai, dan saling menghormati merupakan ajaran inklusivisme yang diperkenalkan oleh Nurcholis Madjid. ${ }^{19}$

Ia juga menegaskan jika Islam haruslah memiliki pegangan terhadap keterbukaan, sikap menerima perbedaan, toleransi dan all inclusive dimana Islam harus mengakui adanya agama lain, adanya ktab suci lain, dan adanya nabi-nabi yang lain. Sehingga dalam urusan sosial maupun agama kita saling bahumembahu bersinergi dalam mencapai tujuan agama yaitu lapang dan terbuka terhadap segala hal. Membantu orang yang menganut agama lain, dalam urusan sosial misalnya. Juga Nurcholis Madjid optimis dengan hal yang disebut puncak daripada orang beragama yaitu "titik temu" semua agama.

Dalam kenyataan yang ada khususnya dalam pandangan Nurcholis Madjid, Indonesia justru dengan keadaaan umat muslim terbesar dan sejalan dengan apa yang disebut mayoritas, maka hanya akan menegasikan penganut agama lain atau penganut kepercayaan lain.

Dengan adanya keadaan yang demikian justru masyarakat enggan untuk berdebat atau berselisih karena dapat dianggap mengurangi kapasitas rahmat yang Tuhan berikan kepada hamba-Nya (dalam hal ini umat Islam). Sehingga dialog yang dimana Nurcholis Madjid optimis dengannya justru menjadi sebuah

\footnotetext{
${ }^{18}$ http://garuda.ristekbrin.go.id/documents/detail/547790

${ }^{19}$ Ibid
} 
penghalang karena mindset masyarakat yang lebih memilih untuk tidak berselisih dengan dalih mendapat rahmat dari Tuhan. Menurut Nurcholis Madjid jelas ini merupakan kekeliruan, bagaimana mungkin kita (Islam) dapat disebut rahmatan Lil alamin jika individunya saja masih menganut paham eksklusivisme. ${ }^{20}$

Sehingga makna Islam sendiri dimata seorang Nurcholis Madjid adalah "pasrah" kepada Tuhan. Maka konsekuensinya adalah, semua agama adalah Islam, baik agama nabi-nabi terdahulu maupun agama yang sekarang, semuanya sama mengajarkan pasrah kepada Tuhan. Maka sejalan dengan itu, senua agama adalah Islam, namun jelas setiap agama memiliki teologinya masing-masing yang kita tidak dapat melakukan intervensi terhadap hal itu. Sehingga sudah jelas, arti, terjemah, ataupun makna Islam versi Nurcholis Madjid adalah pasrah kepada Tuhan. ${ }^{21}$

\section{Analisis Pemikiran Nurcholis Madjid oleh Penulis}

Sehingga jika kita melihat sebagian muballigh sekarang yang kemudian mengklaim bahwa Islam adalah agama yang paling benar, lalu kemudian menegasikan agama maupun keyakinan lain. Tentu tindakan ini bukanlah merupakan tindakan bijak. Secara fenomenologis-historis, Islam datang dan menyebar di Indonesia secara damai dan tanpa klaim sepihak. Mengapa Islam dapat diterima di bumi Nusantara lantaran terdapat walisongo yang menyebarkan Islam secara damai.

Mereka tidak seperti sebagian muballigh masa kini yang justru membuat skisma, namun mereka dengan cerdasnya menyebarkan Islam dengan melakukan pendekatan budaya. Contoh konkretnya adalah, terdapat Sunan Kalijaga misalnya yang memanfaatkan wayang sebagai media dakwah dalam menyebarkan Islam.

Bukankah Islam dahulu disebarkan secara damai oleh wali Allah? Lalu kemudian jika kita melihat kenyataan hari ini, maka sangat menyedihkan sekali, karena para sebagian muballigh membuat wajah Islam menjadi terasa mengerikan dan jauh dari kata-kata damai. 
Dalil-dalil yang kerap mengalami evaporasi nampaknya tidak pernah turun ke bumi dan menjadi hujan. Sehingga banyak sebagian dari muballigh yang jarang sekali membumi, teori-teori mereka hanya mengawang-ngawang dan sulit dipahami.

Uniknya ketika penulis melakukan pengamatan dan diskusi dengan temanteman, ada seorang teman yang berasal dari Tegal Gubug yang mengatakan bahwa di daerahnya kerap kali ditemukan fenomena dimana terdapat salah satu masjid dan dalam khotbahnya (shalat jumat) khatib membawakan ceramah dengan menggunakan bahasa Arab. ${ }^{22}$

Menurut diskusi penulis dengan teman penulis, penulis merasa janggal dan sekidit berpikir, mengapa khotbah Jumat di daerahnya tidak menggunakan bahasa Indonesia saja? Rasionalisasinya adalah masyarakat yang terdapat di daerah Tegal Gubug tak semuanya atau bahkan semuanya dapat mengerti bahasa Arab. Maka secara a priori, jika bahasa yang merupakan alat, digunakan atau diterapkan kepada masyarakat Tegal Gubug dan dimaterialisasikan melalui khotbah Jumat, nampaknya jelas sekali atau bahkan tidak ada yang memahami konten atau isi daripada khotbah tersebut. Sehingga, jemaat yang ada tidak dapat menerima gizi dari khatib dan mereka lebih memilih utnuk melanjutkan mimpinya dengan tertidur.

Maka saat itu pula sesunggunya sang khatib melakukan "kemaksiatan intelektual" karena menutupi informasi dengan penggunaan bahasa Arab yang tidak dimengerti orang-orang Tegal Gubug. Seandainya khatib tersebut menggunakan bahasa Indonesia, tentu angka jemaat yang mengantuk dan tertidur dapat direduksi menjadi lebih sedikit. Mungkin saja jika orang-orang yang mendengarkan khotbah tersebut mengerti jika khatib-nya menggunakan bahasa Indonesia, ada salah satu dari mereka yang tercerahkan dan atau bahkan tersesat oleh paparan yang disampaikan oleh khatib tersebut.

Hal tersebut menunjukkan suatu keangkuhan khatib, dimana secara teori kekuasan Foucault ${ }^{23}$, khatib tersebut memiliki kemampuan bahasa berlebih, dimana ia menguasai bahasa Arab dan para jemaat sebagiannya atau seluruhnya

${ }^{22}$ Diskusi dengan teman penulis

${ }^{23}$ K. Bertens. Sejarah Filsafat Kontemporer Prancis. 2014. Jakarta : Gramedia Pustaka Utama. Hlm. 310 
tidak. Konsekuensinya adalah, khatib menjadi pembicara dan sekaligus pendengar. Jemaat dalam keadaan tersebut berperan sebagai orang yang memahami sang khatib, namun nampaknya jemaat tak kunjung paham, sehingga mereka lebih memilih tidur sebagaimana yang sudah dikatakan sebelumnya.

Dalam kasus lain yang penulis temukan misalnya, terdapat apa yang kemudian disebuat skisma atau perpecahan dalam agama. ${ }^{24}$ Di masa Soeharto, kita mengetahui bahwasannya banyak etnis China yang kemudian didiskriminasi oleh rezim. Hal ini sangatlah empiris, dimana menurut pengakuan ibu penulis yang dimana ia adalah warga Jakarta pada masa itu, pada tahun 1998 tepatnya, terjadi apa yang disebut dengan fenomena bakar-bakaran dan banyak toko-toko yang dimiliki orang beretnis China dibakar serta mereka (orang-orang China) ditelanjangi. ${ }^{25}$

Dalam catatan sejarah, ada sosok negarawan, ada sosok kyai yang sangat luar biasa hebat bernama Abdurrahman Wahid. Dimana ia merupakan salah seorang mayoritas yang peduli terhadap kaum minoritas seperti etnis China yang memang pada saat itu kuantitasnya sangat sedikit. Abdurrahman Wahid atau Gusdur layaknya perekat perpecahan bangsa, Gusdur layaknya rumah bagi kaum minoritas. Ia hadir bagi mereka yang terasingkan, teralienasi, terpinggirkan, dan Gusdur adalah orang yang mampu meredakan kesedihan serta rasa sakit mereka (kaum minoritas) akibat diskriminasi.

Banyak etnis China yang kemudian mengadukan hal ini kepada Gusdur. Reaksi daripada Gusdur sendiri layaknya teman yang nerangkul saat kita terjatuh. Ia sangat welcome sekali terhadap orang-orang yang ber-etnis China. Hingga pada puncak kepedulian Gusdur, organsiasi Islam Tionghoa dan apa yang sekarang kita kenal dengan sebutan Persatuan Islam Tionghoa Indonesia atau PITI, diberikan izin kembali oleh Gusdur setelah dilarang akibat meletusnya Gestapu (G30/S). Gusdur sangat memperhatikan nasib dan eksistensi daripada orang-orang

24 http://garuda.ristekdikti.go.id/documents/detail/520748 diunduh pada 25/02/2020 pukul 05.01

${ }^{25}$ Wawancara dengan ibu penulis 
Tionghoa manakala Orde Baru tak memihak kepada golongan minoritas tersebut. $^{26}$

Dari hal tersebut, kita dapat memahami bahwa karakter Gusdur yang sangat memahami pluralisme sebagai anugerah Tuhan, sangat terlihat dengan jelas. Maka tak jarang orang-orang Indonesia yang memberikan dirinya laqab atau julukan "Bapak Pluralisme".

Berbicara tentang pluralisme, nampaknya kita akan melangkah kepada firman Tuhan yang penulis sebut sebagai sarana legitimasi untuk memperkuat tulisan penulis. Hal ini juga membantu penulis selaku mahasiswa AFI agar terhindar dari serangan orang asing yang kelak melebeli penulis dengan sebutan "kafir." Baik, penulis cantumkan firman Tuhan berikut ini :

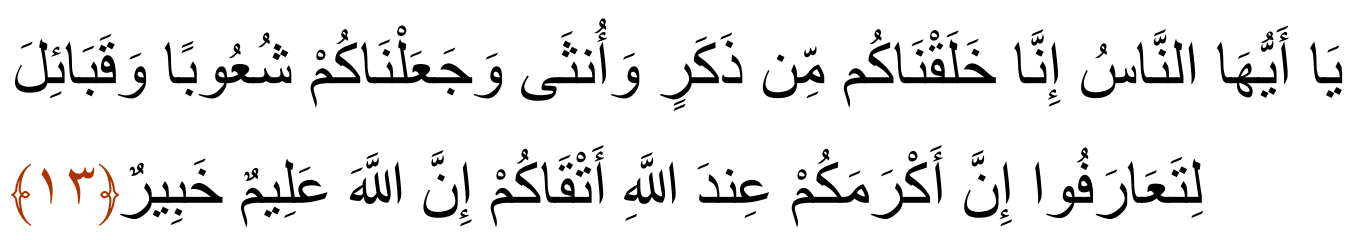

Terjemahan :

"Hai manusia, sesungguhnya Kami menciptakan kamu dari seorang lakilaki dan seorang perempuan dan menjadikan kamu berbangsa-bangsa dan bersuku-suku supaya kamu saling kenal-mengenal. Sesungguhnya orang yang paling mulia di antara kamu di sisi Allah ialah orang yang paling takwa di antara kamu. Sesungguhnya Allah Maha Mengetahui lagi Maha Mengenal.”

Baik, ayat tersebut akan terus menjadi huruf-huruf yang tak bermakna jika tanpa stigma atau interpretasi. Maka perlu adanya intepretasi ayat tersebut dan kita tarik kepada realitas sosial hari ini, khususnya di Indonesia. Maka secara fenomenologis, penulis akan coba menafsirkan ayat ini. Pendekatan yang penulis gunakan adalah fenomenologi dari Edmund Husserl yang dimana suatu teks dapat diuji secara scientific maupun filosofis. ${ }^{27}$ Karena penulis merasa tidak puas hanya dengan mendengarkan hasil tafsir dari pembaharu Islam. Kita butuh sesuatu yang lebih membumi dari membuminya seorang Hasan Hanafi.

\footnotetext{
${ }^{26}$ https://id.m.wikipedia.org/wiki/Persatuan_Islam_Tionghoa_Indonesia

${ }^{27}$ Zainal Abidin. Filsafat Manusia (Memahami Manusia Melalui Filsafat). 2000. Bandung : PT Remaja Rosdakarya. Hlm. 155
} 
Pada kalimat pertama, Tuhan nampaknya sedang berbicara kepada kita (manusia). Hal ini dibuktikan dengan kata "Hai manusia" diawal kalimat. Pada kalimat selanjutnya, yaitu kalimat kedua, Tuhan mencoba untuk memberi tahu kepada kita bahwa hanya terdapat dua jenis manusia di bumi ini, yaitu laki-laki dan perempuan. Apa buktinya?

Dalam kalimat kedua yang juga merupakan firman Tuhan, ia berkata "sesungguhnya Kami menciptakan kamu dari seorang laki-laki dan seorang perempuan." Hal tersebut sangat jelas bahwa memang hanya terdapat dua jenis manusia di bumi ini, secara implisit itu berarti Tuhan tak mengakui jika ada jenis kelamin baru misalnya. Namun diluar sana terdapat orang yang memiliki kelamin ganda, namun tetap saja ia memiliki kecenderungan, sehingga kecenderungan itulah yang nantinya dipilih untuk menjadi identitas seseorang. Kalimat kedua ini masuk dalam ranah ilmu biologi, lebih spesifiknya adalah anatomi tubuh manusia.

Hasil analisis ketiga menurut penulis adalah adanya suatu legitimasi atas apa yang penulis katakan sebagai "informasi pluralisme.” Kalimat ketiga tersebut sangat jelas adanya (eksplisit) bahwa Tuhan menginformasikan kepada kita bahwa ia sendiri yang kemudian menciptakan "perbedaan" di dalam kehidupan manusia. Maka, secara a priori seharusnya kita tidak merasa heran melihat manusia dengan berbagai bentuk dan wujudnya, karena menurut penulis sendiri itu merupakan anugerah Tuhan yang harus kita syukuri keberadaannya.

Tuhan sendiri dalam ayat itu terlihat bahwa ia tak mempedulikan perbedaan diantara manusia, namun ada hal yang sifatnya khusus yaitu -ketaqwaan, menurut Muhammad Abduh sendiri, ketaqwaan adalah salah satu syarat bertemunya kita dengan Tuhan setelah yakin dengan eksistensi-Nya. ${ }^{28}$

Dari semua penjelasan Tuhan dalam firman-Nya, ia pada akhir kalimat hendak memberikan apa tujuan daripada informasi-Nya itu. Maka, the purpose of that verse adalah agar manusia "saling mengenal" satu sama lain. Maka kalau kita sedikit belajar tentang filsafat manusia, kita akan menjumpai dengan istilah yang disebut humanisme. Tujuan Tuhan menciptakan manusia adalah untuk saling mengenal dan saling memahami.

\footnotetext{
${ }^{28}$ Analisis penulis terhadap Q.S Al-Hujurat ayat 13
} 
Maka, tahap selanjutnya setelah mengenal adalah menyayangi. Kita dalam hidup ini sering sekali mendengar istilah "tak kenal maka tak sayang." Nampaknya Tuhan juga memiliki visi yang sama dengan istilah populer tersebut. Sehingga apa yang dinamakan pluralisme nantinya akan Tuhan naungi sendiri kendatipun banyak manusia yang melakukan diskriminasi terhadap golongan tertentu. $^{29}$

Berdasarkan pernyataan Buya Syakur yang penulis peroleh dari tayangan YouTube salah seorang peng-upload dalam tayangan tersebut Buya Syukur mengatakan jika "agama itu diciptakan untuk membuat umat bahagia," ia masih menjelaskan jika "lalu kok kenapa justru sekarang ini, agama membuat orang sulit dan skisma." Hal tersebut merupakan hal yang sifatnya empiris, jika kita melihat kenyataan sosial hari ini, memang benar adanya, kalau kita membuat tesis "jika agama hanya menjadi sumber perpecahan umat," nampaknya akan sangat banyak yang mengafirmasi. ${ }^{30}$

\section{SIMPULAN}

Islam merupakan agama pendatang sehingga secara implisit dapat dikatakan sebagai agama baru. Masuknya Islam ke Nusantara disebabkan oleh adanya faktor salah satunya adalah melalui perdagangan. Terdapat 3 teori yang menjelaskan masuknya Islam ke Nusantara, yaitu Teori Mekah yang digagas oleh Buya Hamka, kemudian ada Teori Persia yang digagas oleh Hoesein Djadjadiningrat, dan satu lagi yaitu Teori Gujarat yang digagas oleh Snouck Hurgronje.

Pada awal datangnya Islam, Islam adalah agama yang membawa kedamaian, hal ini dibuktikan dengan adanya wali sembilan atau yang biasa disebut Walisongo yang merupakan orang-orang yang menyebarkan Islam khususnya di Pulau Jawa. Namun waktu terus berkembang, hingga pada akhirnya agama bukan lagi sebagai pemersatu umat, melainkan hanya melahirkan skisma atau perpecahan agama saja. Dalam keadaan ini, lahirlah tokoh hebat yang membuka cara pandang yang benar-benar moderat, ia merupakan Nurcholis Madjid, seorang santri yang berasal dari Jombang, Jawa Timur yang pernah menempuh pendidikan Universitas Chicago, Amerika Serikat.

\footnotetext{
${ }^{29}$ Hasil analisis penulis terhadap Q.S Al-Hujurat ayat 13

${ }^{30} \mathrm{https} / / /$ youtu.be/zDWkOhlSKOQ
} 
Dengan pemikirannya yang radikal dan liberal, ia dapat menjadi tonggak perubahan bagi bangsa Indonesia bersama dengan rekannya yang lain seperti Abdurrahman Wahid atau Gus Dur, Buya Syakur dan mereka para pembaharu Islam di bumi Nusantara. Dengan demikian, kita harus memahami Islam bukanlah agama, melainkan suatu risalah, suatu ajaran yang memang semua yang ada di bumi ini hakikatnya Islam. Sadar atau tidak sadar, suka atau tidak suka, menerima atau tidak menerima. Karena inti daripada semua ajaran agama adalah "pasrah kepada Tuhan.” Hal tersebut sangat jelas dengan ajaran inklusivisme yang diperkenalkan oleh Nurcholis Madjid. Maka segmentasi, sikap eksklusif harus kita hilangkan karena justru kedua hal tersebut bertentangan dengan ajaran Islam yang rahmatan lill alamin.

Maka sebagai manusia kita harus menerima kodrat jika kita merupakan makhluk sosial, yang mana kita akan sangat mustahil untuk hidup tanpa intervensi orang lain. Mari kita membuka mata kita terhadap segala perbedaan yang ada, baik perbedaan agama, ras, suku, atau perbedaan-perbedaan lain yang berpotensi memecah belah persatuan dan kesatuan dalam bingkai kebhinekaan.

\section{DAFTAR PUSTAKA}

Al-Qur'an. Surat Al-Hujurat (49) ayat 13. Al-Qur'an dan Terjemahannya. Departemen Agama RI.

Enung K Rukiati dan Fenti Hikmawati. Sejarah Pendidikan Islam di Indonesia. Bandung: Pustaka Setia, 2006.

Kamus Besar Bahasa Indonesia (KBBI)

K. Bertens. Sejarah Filsafat Kontemporer Prancis. Jakarta : Gramedia Pustaka Utama, 2014.

Zainal Abidin. Filsafat Manusia (Memahami Manusia Melalui Filsafat). Bandung : PT

Remaja Rosdakarya, 2000.

https://id.m.wikipedia.org/wiki/Persatuan_Islam_Tionghoa_Indonesia

http://garuda.ristekdikti.go.id/documents/detail/90061 diunduh pada 25/02/2020 pukul 05.01

http://garuda.ristekdikti.go.id/documents/detail/942126 diunduh pada 25/02/2020 pukul 05.02 
YAQZHAN | Volume 6, Nomor I, Juli 2020

http://garuda.ristekdikti.go.id/documents/detail/520748 diunduh pada 25/02/2020 pukul 05.03

http://garuda.ristekdikti.go.id/documents/detail/547790 diunduh pada 25/02/2020 pukul 05.04

http://garuda.ristekdikti.go.id/documents/detail/1250181 diunduh pada 25/02/2020 pukul 05.05 